\title{
АКТУАЛЬНІ ПИТАННЯ ЗАБЕЗПЕЧЕННЯ ПСИХОЛОГІЧНӦ̈ БЕЗПЕКИ ОСОБИСТОСТІ ПРОКУРОРА
}

\begin{abstract}
БЕВЗЮК Інна Миколаївна - кандидат психологічних наук, старший викладач відділу підготовки прокурорів з організації роботи в органах прокуратури та викладання професійної етики Інституту спеціальної підготовки Національної академії прокуратури України

КОЗЬЯКОВ Ігор Миколайович - доктор юридичних наук, професор, начальник відділу розробки та впровадження інноваційних методик організації роботи та управління в органах прокуратури НДІ Національної академії прокуратури України
\end{abstract}

DOI:10.32782/NP.2020.1.29

Стаття присвячена розгляду основних категорій психологічної безпеки та ї компонентів, виявленню психотравмуючих $i$ стресогенних чинників професійної діяльності в органах прокуратури, обгрунтуванню моделі організачійноправового забезпечення психологічної безпеки особистості прокурора.

Авторами підтверджено, що наявність психотравмуючих $і$ стресогенних чинників $е$ специбічною ознакою роботи в органах прокуратури. Передусім ними виокремлюються: підвищений рівень юридичної та моральної відповідальності, значний обсяг і тривалість робочого навантаження, невизначеність короткостроковоі перспективи, конбліктогенність, стрімкість, новизна та незвичайність діяльності, раптовість змін, ризик спричинення шкоди прокурору або його близьким тощо.

Обстоюється позичія, що для попередження виникнення у прачівників органів прокуратури синдрому емочиійого (професійного) вигоряння має здійснюватися забезпечення психологічної безпеки особистості прокурора за трьома напрямами: організаиійно-правовому, інтерсуб'єктному та індивідуальному.

Ключові слова: прокурор; професійна діяльність; психологічна безпека особистості; психотравмуючі чинники; стрес; стресогенні чинни$\kappa u$.

\section{Постановка проблеми}

У професійній прокурорській діяльності психологічну безпеку особистості характеризує стан захищеності психіки прокурора від дії різноманітних факторів, що перешкоджають чи ускладнюють формування і функціонування адекватної основи його службової та позаслужбової поведінки і системи суб'єктивного (особистісного) ставлення прокурора до навколишнього оточення, професійного середовища, колег і самого себе.

Передусім, дія цих факторів на організаційному рівні пов'язана 3 сучасними умовами праці, обстановкою на робочому місці, соціально-психологічним кліматом у колективі органу прокуратури. На міжособистісному рівні вона відбувається в процесі взаємовідносин з керівниками, іншими прокурорами, колегами по роботі, працівниками суду та органів правопорядку, громадянами тощо. На рівні свідомості людини головним дестабілізуючим фактором в аспекті психологічної безпеки можна назвати суперечливий характер професійної прокурорської діяльності.

Така особливість обумовлена двома чинниками: по-перше, жорсткістю юридичних вимог до службової діяльності прокурора (детальною урегульованістю, обмеженістю правових засобів, імперативністю вимог до рішень і дії, що приймаються, обмеженістю дискреційних повноважень тощо), по-друге, творчим характером прокурорської професії, розмаїттям функціональних сфер діяльності і завдань, які має вирішувати прокурор; незалежністю, процесуальною та професійною самостійністю, яка детермінує високу особисту відповідальність за прийняті рішення. Варто 
підкреслити, що ця суперечливість діяльності прокурора породжує їі стресогенний характер.

\section{Аналіз останніх досліджень і публікацій}

Моніторинг джерел наукової інформації свідчить, що проблема психологічної безпеки особистості відображена у працях Т. Буленко, А. Василенко, І. Ващенко, Г. Діон, ᄉ. Карамушки, С. Максименко, В. Орел, В. Павелків, О. Саннікова та ін.), зокрема феномен психоемоційного вигорання розглядається в контексті професійної деформації особистості зокрема Г. Абрамовою, В. Бойко, Е. Зеєром, А. Мітіною, Т. Форманюк, О. Щербаковим. Для сучасної літератури характерною є позиція дослідників, які розглядають цю проблематику крізь призму фахової діяльності представників різних професій - працівників сфери обслуговування (Дж. Грінберг, О. Полуніна, Б. Содерфельдт та ін.), медичних працівників (К. Маслач, П. Бланк, В. Шуфелі та ін.), педагогів (В. Кан-Калик, Н. Дідусь, Ю. Кулюткін, Г. Сухобська, Н. Чепелєва, Т. Форманюк, Т. Яценко та ін), співробітників органів правопорядку та військовослужбовців (А. Леженіна, Н. Пов'якель, Е. Потапчук, С. Яковенко та ін.). Проте, професійна діяльність прокурорів у цьому аспекті є малодослідженою.

Метою статті є визначення та характеристика основних категорій психологічної безпеки особистості прокурора, виявлення психотравмуючих і стресогенних чинників професійної діяльності прокурора, обгрунтування моделі організаційно-правового забезпечення цього виду психологічної безпеки.

Виклад основного матеріалу. Якнайперше слід констатувати той науковий факт, що специфічною для роботи в органах прокуратури є наявність психотравмуючих і стресогенних чинників [1]. Зокрема, це підвищений рівень юридичної та моральної відповідальності, значний обсяг і тривалість робочого навантаження, невизначеність короткострокової перспективи, конфліктогенність, стрімкість, новизна та незвичайність діяльності, раптовість змін, ризик спричинення шкоди прокурору або його близьким та ін.[2].

Проведеними дослідженнями встановлено, що $89 \%$ респондентів з 257 опитаних нами працівників місцевих і регіональних прокуратур пов'язують із наведеними вище чинниками виникнення нервово-психічного перевантаження та напруженням емоційно-вольової сфери особистості.

Крім того, результати опитування респондентів свідчать, що сучасну прокурорську діяльність також негативно характеризують фактори соціально-психологічного характеру, зокрема: авторитарний і грубий стиль управління окремими керівниками органу прокуратури підлеглими прокурорами (59\%); конфліктні відносини в колективі (відділі, управлінні) (47\%); несприятливий вплив найближчого соціального оточення поза службою (49\%); необ'єктивну і вкрай низьку суспільну оцінку діяльності органів прокуратури (98\%), радикальні та екстремістські дії громадських активістів щодо прокурорів (82\%), внаслідок чого у прокурорів виникає відчуття безвиході, професійного безсилля й невпевненості у потрібності їхньої професійної діяльності.

Під час дослідження виявлено ще один психологічний фактор прокурорської діяльності, який пов'язаний 3 вимогами професійної доброчесності прокурора (загалом), і конфліктом інтересів (внутрішньоособистісним конфліктом), що доволі часто виникає у свідомості прокурора під час виконання службових обов'язків і позаслужбової поведінки (зокрема). Адже при реалізації прокурорських повноважень він діє на підставі закону (наприклад, п. 6 ч. 1 ст. 3, ст. 18 та інші Закону України «Про прокуратуру», ст. ст. 8, 14, 19, 21, 22 Кодексу професійної етики та поведінки прокурорів тощо), неупереджено, незважаючи на приватні інтереси або особисте ставлення до будь-яких подій та осіб, не спираючись на свої власні ідеологічні, релігійні або інші особисті погляди чи переконання. Крім того, прокурор мусить уникати особистих зв'язків, фінансових і ділових взаємовідносин, що можуть вплинути на неупередженість і об'єктивність виконання професійних обов'язків, скомпрометувати звання 
прокурора, не допускати дій, висловлювань і поведінки, які можуть зашкодити його репутації та авторитету прокуратури, викликати негативний суспільний резонанс.

Варто підкреслити, що в зв'язку з вищеозначеними обставинами професійна діяльність прокурора зумовлює об'єктивні труднощі соціальної взаємодії та передбачає необхідність серйозних обмежень у його поведінці: скорочену можливість для улюблених занять, обмежене коло особистісного спілкування, утруднені або припинені зв'язки з рідними і близькими, неминучу відмову від деяких видів активності та звичок заради інтересів прокурорської служби і виконання вимог правил професійної етики прокурора.

Відтак, наведені негативні чинники професійної діяльності прокурора характеризуються загальним (неспецифічним) впливом на психіку людини, що гальмує реалізацію звичних, відпрацьованих раніше дій, які нею успішно виконувалися у відносно спокійних умовах професійної взаємодії.

Разом $з$ тим наявність значної кількості психотравмуючих i стресогенних чинників, які супроводжують професійну прокурорську діяльність, створюють постійну психологічну напруженість, якою потерпає прокурор, внаслідок чого відбувається виникнення стресового стану.

У психологічній науці обгрунтовано три основні підходи до аналізу професійного стресу:

- по-перше, його причиною є невідповідність (або несумісність) вимог робочого середовища й індивідуальних ресурсів працівника, то важливо виявити дисбаланс у системі „особистість - професійне середовище” і з'ясувати, яким чином слід їі оптимізувати;

- по-друге, оскільки стрес породжується надто високою суб'єктивною оцінкою конфліктної ситуації, то необхідно правильно визначити лінію толерантної і виваженої поведінки для подолання труднощів спілкування;

- по-третє, оскільки стрес призводить до дерегуляції механізмів діяльності, а відтак до „переоцінки” власних можливостей, акумуляції хронічних ефектів, що спричиняє стійкі патологічні зрушення в структурі особистості, то йдеться про впровадження комплексу тренінгових програм для формування вмінь і навичок подолання стресових ситуацій [3].

Тому оцінка стресозалежності працівників органів прокуратури 3 огляду на загальні характеристики правоохоронної діяльності має здійснюватися на базі наведених підходів. Натомість нехтування цими науковими положеннями може призвести до „емоційного вигоряння” працівників, а згодом - до професійної деформації їх особистості.

Наразі проблеми виробничого стресу, який розглядається в рамках синдрому емоційного вигорання (СЕВ), виділений Міжнародною статистичною класифікацією хвороб і проблем, пов'язаних зі здоров'ям (МКХ-10) як „синдром вигоряння” під рубрикою Z.73.0 (проблеми, пов'язані 3 труднощами управління своїм життям). За даними Всесвітньої організації охорони здоров'я, 45\% усіх захворювань пов'язано зі стресом, причому деякі фахівці вважають, що ця цифра в два рази більша [4].

Всесвітня організація охорони здоров'я визначила у 2001 році: „Синдром вигоряння (burnout syndrome) - це фізичне, емоційне або мотиваційне виснаження, що характеризується порушенням продуктивності в роботі і втомою, безсонням, підвищеною схильністю соматичних захворювань, а також вживанням алкоголю або інших психоактивних засобів 3 метою отримати тимчасове полегшення, що має тенденцію до розвитку фізіологічної залежності і (у багатьох випадках) суїцидальної поведінки. Цей синдром зазвичай розцінюється як стрес-реакція у відповідь на безжальні виробничі і емоційні вимоги, що походять від зайвої відданості людини своїй роботі, яку супроводжує зневага сімейним життям або відпочинком" [5].

За результатами досліджень цього явища, психологи діференцюють три основні групи проявів даного стану: 1) емоційну виснаженість, 2) деперсоналізацію, 3) редукцію професійних досягнень. Під емоційним виснаженням розуміють почуття емоційної 
спустошеності й утоми, зумовлених професійною діяльністю. Під деперсоналізацією в даному випадку розуміється не класичне психіатричне поняття даного терміна, а скоріше зниження особистісного компонента - дегуманізація стосунків до об’єктів своєї діяльності (пацієнтам, клієнтам): холодність, формалізація контактів, черствість, цинізм. Виникаючі негативні установки можуть спочатку мати прихований характер і виявлятися внутрішньо, стримуючи роздратування, яке 3 часом проривається назовні і призводить до конфліктів. Редукція особистих професійних досягнень проявляється в заниженні професійних успіхів і виникненні почуття власної некомпетентності у своїй професійній сфері. Робиться акцент на тому, що вигоряння це не втрата творчого потенціалу, не реакція на нудьгу, а радше емоційне виснаження, що виникає на тлі стресу, викликаного міжособистісним спілкуванням [6].

Науковцями-психологами обстоюється позиція, за якою професійна деформація це прояв у особистості під впливом деяких особливостей професійної діяльності таких психологічних змін, які розпочинають негативно впливати на здійснення цієї діяльності та на психологічну структуру особистості. Тому при вивченні проблеми деформації особистості працівників прокуратури необхідно враховувати вплив безлічі внутрішніх і зовнішніх факторів у їх професійній діяльності [7].

Передусім, небезпека професійної деформації особистості прокурора пов'язана не лише з тим, що внаслідок зміни у фаховій правосвідомості ним втрачаються моральні, естетичні, правові, а потім і ділові якості. Поряд із тим існує й суспільна небезпека цього психологічного явища, яка полягає в тому, що дії і настрої прокурора 3 деформованою свідомістю (наприклад, 3 обвинувальним ухилом) призводять до негативних соціальних наслідків у відносинах між органами прокуратури і суспільством.

Також морально-професійна деформація часто стає причиною вчинення працівниками прокуратури протиправних діянь, пов'язаних з порушенням конституційних прав громадян, що, у свою чергу, призво- дить, до підриву такого основоположного принципу національного законодавства, як законність, завдає істотної шкоди авторитету органів державної влади і дискредитує саму ідею побудови правової держави.

Нарешті, професійна деформації прокурорів розглядається нами у каузальному зв'язку із порушеннями норм Кодексу професійної етики та поведінки прокурорів. Встановлено, що результатом деформації є неповноцінне виконання ними своїх професійних обов'язків з об'єктивних причин, або через свідоме несумлінне виконання службових обов'язків.

Висновки. Таким чином, наразі професійне емоційне вигорання є однією з основних загроз психологічній безпеці особистості у прокурорській діяльності. Убезпечити себе від цієї форми професійної деформації прокуророві можливо лише внаслідок створення відвідного стану захищеності власної особистості, за якого зберігається iї цілісність як активного та ефективного суб'єкта прокурорської діяльності, а також виникають і створюються можливості особистісного розвитку в умовах сучасної взаємодії з професійним середовищем. Інакше кажучи, на особистісному рівні йдеться про стан внутрішнього благополуччя, що $є$ наслідком усвідомлення прокурором своєї здатності долати несприятливі зовнішні та внутрішні впливи, забезпечуючи тим самим для себе сталий розвиток особистості, професійне зростання.

Отже, прокурор, ясно розуміючи своє положення в навколишньому професійному середовищі, так само ясно має розуміти наявні можливості та розраховувати на них за для убезпечення своєї безпеки і подолання професійного вигоряння.

Відтак, наявність значної кількості психотравмуючих і стресогенних чинників, які супроводжують прокурорську діяльність, мають розглядатися як загрози психологічної безпеки особистості прокурора. Вони детермінуються та усвідомлюються особистістю як суттєво виражена невідповідність цінностей суб'єкта професійної діяльності в органах прокуратури з характеристиками навколишнього (професійного) середовища та наявних у певний період діяльності 
ресурсів. Подолання вказаної аксіологічної невідповідності між системою правових і морально-етичних цінностей прокурора та негативних (деформуючих) середовищних характеристик професійної діяльності грунтується на активності самого суб'єкта такої діяльності. Відповідно, особистість прокурора розглядається як суб'єкт активності у сфері психологічної безпеки.

При тому варто підкреслити, що загалом відмінною рисою суб'єкта забезпечення безпеки, щонайперше, є здатність регулювати процес планування і реалізації цілей діяльності. Отже, таке регулювання можливе лише за умови здійснення прокурором об'єктивної оцінки власних можливостей і ресурсів.

Первинний етап оцінки пов'язаний iз самодіагностикою стресового стану. Для цього прокурор має визначити в себе (за почуттями, спостереженнями та самооцінками) загальні ознаки стресового стану. До них належать: 1) неможливість зосередитися у процесі службової діяльності; 2) допущення значної кількості помилок, 3) погіршення пам'яті, 4) високий рівень перевтоми, 5) швидкий темп мовлення, 6) розосередження мисленнєвої діяльності, 7) погіршення настрою, 8) зниження загального емоційного стану, 9) зацикленість на другорядних деталях, 10) сонливість тощо. Якщо при тому виявляється більше ніж три симптоми, стан вважається стресовим і потребує звернення до кваліфікованого фахівця по психологічну допомогу (підтримку).

Метою психологічної підтримки є виявлення психофізіологічних чинників, які впливають на формування психологічної безпеки особистості, потенціалу особистості, ціннісних орієнтацій, емоційної компетентності, що в подальшому дає можливість сформувати установку готовності до самозміни, спрямованої на самопізнання, саморозвиток, самореалізацію, саморегуляцію, самовдосконалення.

Після проведення діагностики, консультації та корекції наступним етапом 6 навчання прогнозуванню (розвиток антіципаційної спроможності), планування результату дії. Унаслідок підвищується рівень прогностичної компетентності прокурора, i він набуває здатності вчасно та адекватно відреагувати на різні ситуації (в тому числі й екстремальні) та зберегти психологічну безпеку особистості.

Викладеним обгрунтовується пропозиція щодо створення в органах прокуратури спеціалізованої психологічної служби, до завдань якої має входити виконання зазначених вище функцій.

У подальшому зосередимося ще на одному аспекті психологічної безпеки прокурора, пов'язаному з тривалим стресовим станом і розвитком синдрому емоційного вигорання. На сьогодні напрацьовано багато рекомендацій 3 діагностики та профілактики (зокрема самодопомога, самокорекція, самозахист) деструктивного стресу та професійного вигорання, починаючи від науково обгрунтованих підходів з подолання професійних деформацій до настанов „допоможи собі сам”. Зазначається, що в діагностичному аспекті симптоми емоційного вигорання умовно поділяються на фізичні, поведінкові та психологічні [8;9].

До фізичних симптомів відносяться: втома, відчуття виснаження, сприйнятливість до змін показників зовнішнього середовища, астенізація, часті головні болі, розлади шлунково-кишкового тракту, надлишок або недолік ваги, задишка, безсоння. До поведінкових і психологічних симптомів відносяться: поява почуття неусвідомленого занепокоєння, нудьги, образи, розчарування, провини, незатребуваності; зниження рівня ентузіазму; дратівливість; поява труднощів при прийнятті рішень; дистанціювання від клієнтів/ пацієнтів і прагнення до дистанціювання від колег, загальна негативна установка на життеві перспективи

3 метою протидії розвиткові синдрому емоційного (професійного) вигоряння прокурора та створення стану захищеності його психіки від інших негативних чинників, пропонуємо теоретичну модель психологічної безпеки особистості прокурора.

Ïї реалізація може бути здійснена за трьома рівнями.

1. Організаційно-правовий рівень, на якому мають вирішуватися питання, що 
пов'язані 3 посиленням прокурорської незалежності, оптимізацією організації та управління в органах прокуратури, поліпшенням умов праці прокурорів. Вважаємо, що в нормативно-правовому аспекті організації роботи потрібно:

а) внести зміни до законодавства, якими забезпечити відновлення функціонування органів прокурорського самоврядування, Кваліфікаційно-дисциплінарної комісії прокурорів, порядку відбору й призначення прокурорів на адміністративні посади (передусім, на посади керівників органів прокуратури), притягнення прокурорів до дисциплінарної відповідальності тощо;

б) привести у відповідність до міжнародних стандартів процедуру проведення атестації прокурорів, що здійснюється відповідно до розділу II «Прикінцеві і перехідні положення» Закону України від 19 вересня 2019 року № 113-IX «Про внесення змін до деяких законодавчих актів України щодо першочергових заходів із реформи органів прокуратури». Зокрема, варто мінімізувати суб'єктивні чинники та фактори зовнішнього впливу на формування складу та діяльність кадрових комісій Офісу Генерального прокурора, кадрових обласних прокуратур. Доцільно також встановити обов'язкове ведення протоколу засідання таких комісій із фіксацією технічними засобами. Особливо це стосується проведення співбесіди з метою виявлення відповідності прокурора вимогам професійної компетентності, професійної етики та доброчесності;

в) розробити на основі наукової організації праці та прийняти порядок вимірювання та регулювання навантаження на прокурорів;

г) впровадити релевантну та валідну систему індивідуального оцінювання якості роботи прокурорів, замінивши нею зазначену вище атестацію прокурорів.

2. Інтерсуб'єктний рівень - зумовлює оптимізацію взаємовідносин 3 колегами, підлеглими працівниками, учасниками судочинства.

3. Індивідуальний рівень характеризує а) профілактика: вироблення адаптивних форм поведінки, застосування захисних психологічних механізмів;

б) лікування клінічних проявів у разі враження психосоматичної системи або виникнення хворобливого стану;

Найефективнішою формою засвоєння й розвитку адаптивних форм поведінки особистості 3 метою профілактики стресового стану та протидії стресорам професійної діяльності прокурора ми вважаємо проведення психологічних тренінгів, які під час підвищення кваліфікації успішно проходили слухачі Національної академії прокуратури України.

У процесі проведеного дослідження доведено, що здійснення спеціальної підготовки кандидатів на посаду прокурора та постійної підготовки прокурорів у режимі підвищення професійної кваліфікації передбачає формування та розвиток аутопсихологічної компетентності.

Будучи компонентом психологічної компетентності прокурора, аутопсихологічна компетентність $\epsilon$ інтегральним показником здатності особистості до самокорекції, що охоплює психофізіологічний, психічний, соціальний i духовний рівні психічного життя (самопізнання, вміння вивчати себе, самооцінка, самоконтроль, уміння управляти своїм психологічним станом і працездатністю, самоефективність).

Тому для забезпечення психологічної безпеки особистості прокурора важливу роль відіграє індивідуальний рівень, на якому має бути реалізована психологічна самопідготовка, що здійснюеться самим прокурором з використанням раніше отриманих психологічних знань, умінь i навичок. Адже це обумовлено потребою самостійно протидіяти стресорам і протистояти виникаючим негативним емоційним переживанням, що з'являються під впливом психотравмуючих і стресогенних чинників професійної прокурорської діяльності.

Перспективи подальшого розгляду проблеми забезпечення психологічної безпеки особистості прокурора вбачаються в дослідженні крізь призму фахових ознак параметрів прокурорської діяльності за вста- 


\section{Філософія та психологія права}

новленими Конституцією України функціями прокуратури та розробки пропозицій щодо удосконалення законодавства, відомчої нормативно-правової бази і професійної підготовки прокурорів.

\section{Література}

1. Анушкевич В.А. Роль саморегуляції в успішності професійної діяльності прокурорів: автореф. дис. на здобуття наук. ступеня канд. психол. наук: 19.00.06. Харк. нац. ун-т внутр. справ. Х., 2008. 16 с.

2. Бевзюк I. Психотравмуючі та стресогенні чинники професійної діяльності прокурора. Науковий часопис Національної академії прокуратури України. 2018.№ 2(18). C. 15-24<http://www.chasopysnapu. gp.gov.ua/ua/pdf/2-2018/bevzuk.pdf >

3. Кисіль 3., Кисіль Р.-В.. Психологічні чинники професійного стресу у працівників Національної поліції України. Соціально-правові студії. 2019. Вип. 1 (3). С. 28-29.

4. Вербина Г. Психология эмоций: учеб. пособие. Чебоксары, 2008. С. 12.

5. Юрьева $\lambda$. Профессиональное выгорание у медицинских работников: формирование, профилактика, коррекция. К.: Сфера, 2004. С. 9.

6. Maslach, C., \& Jackson, S.E. (1986). Maslach burnout inventory manual (2nd ed.). Palo Alto, CA: Consulting Psychologists Press.

7. Кобец А. Психологические аспекты профессиональных. кризисов и деформаций в деятельности работников. прокуратуры и их профилактика. Актуальні проблеми психології: 36. наук. праць Інституту психології імені Г.С. Костюка НАПН України. К.:
Видавництво „Фенікс”, 2014. Т. ХІІ. Психологія творчості. Вип. 19. 177-185.

8. Брецко I.I. Психологічна симптоматика емоційного вигорання особистості. Проблеми сучасної психології. Збірник наукових праць К-ПНУ імені Івана Огієнка. Інституту психології ім. Г.С. Костюка НАПН України. 2011. Вип. №12. С. 110120.

9. Чутко А.С., Козина Н.В. Синдром эмоционального выгорания. Клинические и психологические аспекты. 3-е изд. М. : МЕДпресс-информ, 2015. 256 с.

\section{Inna Bevziuk, Igor Koziakov ACTUAL ISSUES ON ENSURING THE PSYCHOLOGICAL SAFETY OF THE PROSECUTOR'S PERSONALITY}

The article aimed on basic categories of psychological safety and its components, identification of psychotraumatic and stressful factors of professional activity in the prosecution bodies, model of ensuring the psychological safety of the prosecutor's personality.

The authors confirmed that presence of psychotraumatic and stressful factors is a specific work feature in the prosecution bodies. Among them: increased level of legal and moral responsibility, workload and its duration, uncertainty of working conditions for the near future, conflictogenicity, rapidity, newness and singularity of activity, suddenly changes, risk for the prosecutor or his relatives to be harmed etc.

It's confirmed that for prevention of prosecutor's emotion (professional) burnout syndrome, psychological safety of the prosecutor's personality should be provided in three directions: organizational and legal, intersubjective and individual.

Keywords: the prosecutor; professional activity; psychological safety of the personality; psychotraumatic factors; stress; stressful factors. 